\title{
PENGEMBANGAN BAHAN AJAR KETERAMPILAN MEMBACA MODEL GRAVES MAHASISWA BIPA
}

The Development of Graves Model's Reading Skills Teaching Materials for BIPA Students

\author{
Dian Uswatun Hasanah ${ }^{1}$, Dwi Kurniasih ${ }^{2}$ dan Novita Nurul Halimah ${ }^{3}$ \\ ${ }^{1,3}$ Universitas Islam Negeri Raden Mas Said Surakarta \\ ${ }^{2}$ Universitas Sebelas Maret \\ dianneuh@gmail.com
}

Naskah Diterima Tanggal 2 Desember 2019_Direvisi Akhir Tanggal 23 Februari 2021—Disetujui Tanggal 1 Juni 2021 doi: https://doi.org/10.26499/rnh.v10i1.1872

\begin{abstract}
Abstrak
Penelitian ini bertujuan untuk mengembangkan materi ajar BIPA pada keterampilan membaca dengan model Graves pada mahasiswa BIPA di UIN Raden Mas Said Surakarta. Penelitian ini menggunakan metode penelitian kualitatif yang disesuaikan dengan kondisi di lapangan. Tahapan model Graves yang dilaksanakan ini ada empat tahap, yaitu: 1) analisis kebutuhan, 2) menentukan tujuan umum dan khusus, 3) memilah dan menyeleksi materi ajar dan aktivitas yang dikembangkan, dan 4) mengorganisasikan isi dan aktivitas bahan ajar. Data dikumpulkan dengan cara data pengembangan bahan ajar dan data uji coba. Analisis data menggunakan analisis data pengembangan dan analisis data uji coba bahan ajar. Hasil penelitian menunjukkan bahwa penyusunan bahan ajar membaca BIPA UIN Raden Mas Said Surakarta mempunyai ciri khas tersendiri. Kekhasan tersebut terdapat pada tema yang digunakan dalam bahan ajar yakni "Belajar Bahasa Indonesia Melalui Kearifan Budaya". Melalui materi dalam bahan ajar membaca, mahasiswa asing diperkenalkan tentang ragam budaya yang terdapat di Indonesia, khususnya di Kota Solo. Dengan demikian, tidak hanya bahasa yang menjadi fokus pembelajarannya, tetapi juga budaya dan nilai-nilai keislaman yang berlaku. Hal tersebut dilakukan dengan pertimbangan bahwa lembaga BIPA berada di bawah PTKIN sehingga mahasiswa asing yang belajar di UIN Raden Mas Said Surakarta, diwajibkan memiliki pengetahuan mengenai bahasa, budaya, dan wawasan keislaman. Selain itu, produk hasil pengembangan bahan ajar BIPA keterampilan membaca tidak hanya diproduksi dalam bentuk hard file. Akan tetapi, dalam bentuk $e$ book dengan format PDF. Penggunaan bahan ajar dalam bentuk buku elektronik dapat memudahkan mahasiswa asing untuk mengakses dan mempelajarinya.
\end{abstract}

Kata kunci: pengembangan; model Graves; keterampilan membaca, BIPA

\begin{abstract}
This study aims to develop BIPA teaching materials on reading skills with Graves model. This study uses qualitative research methods that are adapted to conditions in the field. The stages of the Graves model implemented are four stages, namely: 1) needs analysis, 2) determining general and specific objectives, 3) sorting and selecting teaching materials and activities developed, and 4) organizing the content and activities of teaching materials. The results showed that the preparation of teaching materials for reading BIPA UIN Raden Mas Said Surakarta has its own characteristics. This specialty is found in the theme used in teaching materials, namely "Learning Indonesian Through Cultural Wisdom". Through the material in reading teaching materials, foreign students are introduced to the variety of cultures found in Indonesia, especially in the city of Solo. So, not only language is the focus of learning, but also the culture and Islamic values that apply. This was done with the consideration that the BIPA institution was under PTKIN so that foreign students studying at UIN Raden Mas Said
\end{abstract}


Surakarta, were required to have knowledge about language, culture, and Islamic insight. In addition, products developed by BIPA teaching materials for reading skills are not only produced in the form of hard files. However, in the form of e-books in PDF format. The use of teaching materials in the form of electronic books can make it easier for foreign students to access and study them.

Keywords: development; Graves model; reading skills, BIPA

How to Cite: Hasanah, Dian Uswatun, Dwi Kurniasih dan Novita Nurul Halimah. (2021). Pengembangan Bahan Ajar Keterampilan Membaca Model Graves Mahasiswa BIPA. Ranah: Jurnal Kajian Bahasa. 10(1). 22-38. doi: https://doi.org/10.26499/rnh.v10i1.1872

\section{PENDAHULUAN}

Perkembangan Bahasa Indonesia bagi Penutur Asing (BIPA) di dalam dan di luar negeri dari tahun ke tahun semakin meningkat. Terbukti Badan Pengembangan dan Pembinaan Bahasa setiap tahunnya menyeleksi calon tenaga pengajar BIPA untuk ditempatkan di luar negeri. Pada tahun 2019 Badan Bahasa, Kemendikbudristek telah mengirimkan sebanyak 220 pengajar ke 30 negara. Secara keseluruhan, Kemendikbudristek telah mengirimkan 793 penugasan pengajar Bahasa Indonesia untuk Penutur Asing ke 29 negara. Ada negara yang dikirimkan pengajar Bahasa Indonesia untuk Penutur Asing berulang-ulang. Ada negara yang setiap tahun meminta (dikirimkan) pengajar Bahasa Indonesia untuk Penutur Asing (Prodjo, 2020).

Meningkatnya pengguna Bahasa Indonesia bagi penutur asing memberikan pengaruh yang cukup besar dalam pengajaran BIPA (Andayani, 2015; Hasanah, Kurniasih, \& Agustina, 2019). Pengajaran BIPA jadi semakin diminati, baik di dalam maupun di luar negeri. Minat yang cukup besar tersebut tentunya harus diimbangi dengan tenaga pengajar BIPA yang siap dan berkompetensi (Kusmiatun, 2016). Salah satu bentuk kompetensi yang perlu dimiliki seorang pengajar BIPA adalah dalam hal menyiapkan materi ajar. Dalam pembuatannya, materi ajar yang disiapkan harus menyesuaikan dengan kebutuhan belajar siswa atau mahasiswa, sebab pelajar BIPA memiliki latar belakang budaya dan bahasa yang berbeda dengan budaya dan bahasa yang akan mereka pelajari (Kurniasih, 2021).

Di lingkup Kementerian Agama, baru ada empat perguruan tinggi yang dapat menyelenggarakan pembinaan bahasa bagi mahasiswa asing melalui BIPA (Ulfiana, 2017). Empat perguruan tinggi tersebut adalah UIN Maulana Malik Ibrahim Malang, UIN Sunan Kalijaga Yogyakarta, UIN Syarif Hidayatullah Jakarta, dan UIN Raden Mas Said Surakarta. BIPA di UIN Raden Mas Said Surakarta termasuk program baru yang sudah mendapat SK Rektor pada tahun 2017. Oleh karena itu, kesiapan perguruan tinggi di lingkup PTKIN khususnya, dalam penyelenggaraan BIPA ini perlu dimaksimalkan dalam segala hal, mulai dari sumber daya manusia pengajar BIPA, sarana dan prasarana, hingga metode serta materi ajar. (Kurniasih \& Isnaniah, 2019). Oleh karena itu, perlu adanya pengembangan bahan ajar yang dibuat khusus di lingkup PTKIN agar kurikulum yang terdapat dalam bahan ajar tersebut sesuai dengan visi dan misi PTKIN sebagai lembaga yang bercirikan Islamic studies.

Dalam hal materi ajar, sampai saat ini belum ada bahan ajar BIPA yang dikhususkan untuk mahasiswa BIPA yang menempuh studi di PTKIN (Perguruan Tinggi Keagamaan Islam Negeri). Bahan ajar yang biasa digunakan oleh para pengajar BIPA di PTKIN adalah bahan ajar yang bersumber dari Badan Bahasa. Bahan ajar BIPA UIN Raden Mas Said Surakarta disusun dengan mengintegrasikan kurikulum BIPA Badan Bahasa dengan wawasan budaya dan keislaman yang terdapat di lingkungan sekitar dan berkaitan dengan kehidupan sehari-hari. Dalam mempelajari bahasa Indonesia, orang asing dapat mendalami pembelajaran bahasa secara faktual dan didukung dengan pemahaman akan khazanah budaya (Andayani \& Gilang, 2015; Haryati, Andayani, \& Anindyarini, 2019). Cakupan materi yang terdapat dalam 
bahan ajar ini meliputi dua level, yaitu A1 dan A2. Bahan ajar ini disusun dengan mempertimbangkan kebutuhan mahasiswa BIPA.

Mengembangkan buku ajar merupakan kemampuan yang perlu ditingkatkan oleh dosen di Perguruan Tinggi (Van Peer, Zyngier, Klinger, \& Tosheff, 2010). Jika seorang dosen tidak memiliki kemampuan mengembangkan buku ajar yang bervariasi, situasi pembelajaran di kelas dapat membosankan bagi mahasiswanya (Chen, Lawrence, Zhou, Min, \& Snow, 2018). Buku ajar merupakan bagian yang penting dalam pembelajaran karena dapat digunakan sebagai sumber belajar, baik bagi dosen maupun mahasiswa (O'Toole \& Kannass, 2018). Materi ajar dapat dikembangkan dengan berbagai model, antara lain model Hutchinson dan Waters, model Brown, model Graves, model Jolly dan Bolitho, model Tomlinson, dan lainlain. Di antara beberapa model tersebut, peneliti tertarik untuk mengembangkan bahan ajar dengan model Graves. Alasan pemilihan model tersebut karena model ini sangat memperhatikan analisis kebutuhan dan sumber daya manusia. Bahan ajar yang akan dikembangkan adalah bahan ajar berupa buku.

Penelitian terkait pengembangan bahan ajar BIPA pernah dilakukan oleh (Siroj, 2015) dalam Jurnal Pendidikan Bahasa dan Sastra Indonesia dengan judul Pengembangan Model Integratif Bahan Ajar Bahasa Indonesia Ranah Sosial Budaya Berbasis ICT bagi Penutur Asing Tingkat Menengah. Hasil penelitian berdasarkan hasil uji coba produk menunjukkan adanya peningkatan rata-rata nilai kemampuan komunikatif pembelajar, yakni dari 57 menjadi 75. Siroj melaporkan bahwa model integratif bahan ajar BIPA ranah sosial budaya berbasis ICT tingkat menengah ini mampu meningkatkan kefasihan pemelajar asing dalam berbicara.

Penelitian serupa pernah pula dilakukan oleh (Fariqoh, 2016) dalam jurnal Riksa Bahasa dengan judul Pengembangan Bahan Ajar Membaca untuk Pembelajar Bahasa Indonesia Penutur Asing Tingkat Dasar. Hasil penelitiannya menunjukkan bahwa bahan ajar yang dikembangkan sudah cukup memenuhi kebutuhan pemelajar, meskipun perlu direvisi karena beberapa kekurangan seperti: kosakata dan struktur bacaan.

Persamaan penelitian ini dengan penelitian sebelumnya pada objek yang dikaji yakni bahan ajar BIPA. Sementara itu, metode yang digunakan termasuk ke dalam jenis penelitian pengembangan atau Research and Development. Perbedaannya ialah pada fokus kajian dalam penelitian ini adalah pengembangan materi ajar BIPA dengan menggunakan model Graves yang bertujuan untuk mengembangkan materi ajar BIPA khususnya keterampilan membaca. Selain itu, hasil produk bahan ajar keterampilan membaca BIPA diproduksi dalam bentuk buku cetak dan elektronik.

Penelitian lain yang memiliki relevansi dengan penelitian ini adalah milik (Nurlina, Andayani, Winarni, \& Slamet, 2020) dalam International Journal of Innovation, Creativity and Change berjudul Development of Local Cultured Textbook for Improving the Speaking Ability of Foreign Workers in Indonesia. Hasil penelitiannya menunjukan bahwa beberapa pembelajaran Bahasa Indonesia belum memiliki materi pembelajaran yang tepat khususnya pemahaman budaya lokal sehingga penelitian ini bertujuan untuk mengembangkannya. Penelitian dan pengembangan ini memiliki tiga tahapan utama yaitu tahap eksplorasi, pengembangan, dan eksperimental.

Penelitian tersebut menggunakan pendekatan penelitian dan pengembangan (R\&D) yang diadaptasi dari Borg, Gall, dan Gall (2007). Desain penelitiannya adalah deskriptif kualitatif dengan mengambil sampel studi Bahasa Indonesia di Universitas Muhammadiyah Purwokerto. Instrumen yang digunakan adalah angket, tes (sebelum dan sesudah tes), formulir analisis buku, dan beberapa daftar pertanyaan untuk wawancara siswa dan guru. Pengumpulan data dilakukan dengan mengumpulkan jawaban dan tes, menganalisis konten budaya pada buku teks, dan menulis jawaban wawancara siswa dan instruktur. Tahapan ini mencoba 
mencari kelemahan dan manfaat buku teks sebelumnya, silabus, dan gambaran tentang kekuatan, kelemahan, peluang, dan ancaman dari buku teks yang sarat budaya lokal.

Penelitian ini menggunakan pendekatan penelitian dan pengembangan yang diadaptasi dari Graves dengan tahapan teknik analisis data pengembangan dan teknik analisis data uji coba bahan ajar. Data pengembangan dilakukan melalui (1) transkipsi data verbal dari hasil wawancara dengan ahli dan pengajar BIPA, (2) pembuatan peta penyusunan bahan ajar, (3) pembuatan RPP, dan (4) penulisan dan penyusunan bahan ajar. Sementara itu, teknik pengumpulan data dan uji coba dilakukan dengan cara (1) mengumpulkan data verbal yang diperoleh dari hasil wawancara dan data diri angket, (2) mencatat data-data yang masuk secara lisan dan tulis, (3) menghimpun, menyeleksi, dan mengklarifikasi data yang sudah masuk, dan (4) menganalisis dan merumuskan hasil analisis untuk digunakan dalam penyelesaian akhir pengembangan bahan ajar keterampilan membaca untuk mahasiswa BIPA UIN Raden Mas Said Surakarta.

Berdasarkan pemaparan tersebut, maka peneliti tertarik untuk mengembangkan materi ajar model Graves untuk keterampilan membaca mahasiswa BIPA di UIN Raden Mas Said Surakarta. Pengembangan materi ajar ini diharapkan dapat memotivasi mahasiswa BIPA untuk memiliki minat yang tinggi dalam belajar Bahasa Indonesia. Lebih lanjut lagi, dalam praktiknya, pengembangan materi ajar ini akan membuat pembelajaran BIPA di masa yang akan datang akan semakin efektif, inovatif, menyenangkan, dan sesuai kemampuan mahasiswa. Hal ini dibuktikan dengan diterbitkannya buku ajar membaca BIPA dalam bentuk cetak dan elektronik, sesuai dengan proses pembelajaran di era digital yang sarat dengan penggunaan gawai.

Penelitian ini dapat memberikan kontribusi dalam pelaksanaan pembelajaran keterampilan membaca bagi mahasiswa BIPA, khususnya di UIN Raden Mas Said Surakarta. Hasil dari penelitian ini diharapkan mampu memberikan standard penerapan model pengembangan materi ajar keterampilan membaca bagi mahasiswa BIPA.

\section{LANDASAN TEORI}

Materi ajar adalah segala bentuk bahan yang digunakan untuk membantu guru atauinstruktur dalam melaksanakan kegiatan belajar mengajar di kelas. Bahan yang dimaksud, dapat berupa bahan tertulis maupun tidak tertulis. Belawati dalam (dalam Prastowo, 2011: 41) menjelaskan bahwa bahan ajar menurut kerjanya dibedakan menjadi lima macam, yaitu bahan ajar yang tidak diproyeksikan, bahan ajar yang diproyeksikan, bahan ajar audio, bahan ajar video, dan bahan ajar komputer.

Mengembangkan buku ajar merupakan kemampuan yang harus dimiliki dosen di Perguruan Tinggi (Van Peer et al., 2010). Kemampuan mengembangkan buku ajar yang bervariasi merupakan upaya menciptakan pembelajaran yang tidak membosankan (Chen et al., 2018). Menurut (Tsuji et al., 2014), buku ajar yang baik meliputi karakteristik, (1) menimbulkan minat baca; (2) ditulis dan dirancang untuk mahasiswa; (3) menjelaskan tujuan instruksional; (4) disusun berdasarkan pola belajar yang fleksibel akan dicapai; (5) memberikan kesempatan pada mahasiswa untuk berlatih; (6) mengakomodasi kesulitan mahasiswa; (7) memberikan rangkuman; dan (8) gaya penulisan komunikatif dan semi formal. Buku ajar yang memenuhi karakteristik dapat menjadi media komunikasi antara dosen dan mahasiswa (Jarvis \& Baloyi, 2020).

Menurut (Graves, 1996: 12) pengembangan materi ajar dapat dibagi menjadi beberapa komponen dan subproses, sesuai dengan pengembangan kurikulum. Proses perencanaan dan penentuan topik per unit beserta aktivitas yang akan dilakukan pada unit tersebut dilakukan untuk memenuhi tujuan sebagai tahap pengembangan materi (Nurlina, 2017; Sumaryani, 
2020). Kerangka komponen modul yang dikemukakan oleh Graves (1996: 12) adalah sebagai berikut.

1. Needs assessment

Mencari kebutuhan mahasiswa asing sehingga pengajar dapat mengembangkan materi dengan tepat.

2. Determining goals and objectives

Apa sebenarnya tujuan pembelajaran BIPA dan apa yang dibutuhkan mahasiswa asing atau bagaimana cara mahasiswa asing mencapai tujuan pembelajaran?

3. Selecting and developing materials and activities

Memilih dan mengembangkan materi, bagaimana dan dengan cara apa pengajar mengajarkannya? Apa peran pengajar, apa peran mahasiswa?

4. Organization of content and activities

Bagaimana pengajar mengatur isi dan kegiatan dalam pembelajaran BIPA?

5. Evaluation

Bagaimana cara pengajar menilai apa yang sudah dipelajari mahasiswa asing? Bagaimana pengajar menilai keefektifan pembelajaran?

6. Consideration of resources and constraints

Pertimbangan dan sumber-sumber lain yang digunakan. Apa manfaat pembelajaran?

1. Beberapa komponen kegiatan yang dilakukan dalam mengembangkan materi ajar adalah sebagai berikut: 1) analisis kebutuhan bahan ajar, 2) penentuan tujuan umum dan tujuan khusus bahan ajar, 3) pemilahan dan penyeleksian bahan ajar, dan 4) pengorganisasian isi dan aktivitas bahan ajar. Menganalisis kebutuhan

Kegiatan ini mencakup dua hal utama yaitu apa yang dibutuhkan pemelajar dan bagaimana cara mengakses dan mendapatkan kebutuhan tersebut. Kegiatan ini dapat juga diidentifikasi melalui latar belakang siswa, seperti negara dan budaya, pendidikan dan akademik, profesi dan calon profesi, umur, bahasa, kemampuan awal siswa mengenai bahasa yang akan dipelajari, dan kegunaan bahasa di masyarakat dan dunia kerja.

2. Menentukan tujuan umum dan khusus

Yang harus dilakukan pada komponen ini adalah menetapkan tujuan dan hasil dari materi ajar yang dirancang. Bagian ini juga menyatakan apa yang perlu dilakukan siswa untuk mencapai tujuan tersebut.

3. Mengonseptualisasi isi

Pengembang materi ajar pada langkah ini harus mengonsepsikan dan merealisasikan aspek-aspek kebahasaan yang harus diajarkan dan bagaimana proses belajar mengajar itu berlangsung.

4. Memilah dan menyeleksi materi ajar dan aktivitas yang dikembangkan.

Pada langkah ini, pengembang harus memilah dan menyeleksi materi ajar sesuai dengan aktivitas pembelajaran yang direncanakan. Semua aktivitas diharapkan mendukung pencapaian tujuan yang telah ditetapkan pada langkah sebelumnya.

5. Mengorganisasikan isi dan aktivitas

Pada langkah ini, pengembang materi harus mengorganisasikan isi materi pelajaran yang dapat memudahkan siswa belajar. Organisasi materi tersebut tentu akan berdampak pada aktivitas yang akan dilakukan siswa.

6. Merancang evaluasi

Pada komponen ini, dua hal penting yang harus dilakukan oleh pengembang materi adalah merancang evaluasi untuk mengetahui apa saja yang telah dipelajari siswa dan bagaimana efektivitas materi tersebut.Kegiatan tersebut memerlukan instrumen yang tepat. 
7. Mempertimbangkan sumber daya dan hambatannya.

Komponen terakhir adalah mengidentifikasi berbagai sumber daya pendukung dalam pengembangan materi ajar dan memperhitungkan kendala yang dihadapi pengembang.

Membaca merupakan suatu keterampilan yang memerlukan suatu latihan yang intensif, teratur, dan berkesinambungan. Oleh karena itu, untuk menilai kegiatan tersebut pendidik dapat menerapkan Taksonomi Bloom. Menurut Bloom untuk menilai prestasi siswa dalam belajar perlu memperhatikan tiga ranah perilaku, yaitu ranah kognitif, afektif, dan psikomotorik. Alat penilaian ranah kognitif menggunakan teknis tes, sedangkan untuk kedua ranah terakhir lebih cocok menggunakan teknis nontes. Bentuk-bentuk nontes ini dapat berupa, wawancara, observasi, angket, skala bertingkat, dan lain-lain (Hidayat, 2009).

\section{METODE PENELITIAN}

Model pengembangan bahan ajar ini mengadaptasi model pengembangan bahan ajar model Graves dengan menyesuaikan kondisi di lapangan. Tahapan model Graves yang dilaksanakan di penelitian ini ada empat tahap, yaitu 1) menganalisis kebutuhan, 2) menentukan tujuan umum dan khusus, 3) memilah dan menyeleksi materi ajar dan aktivitas yang dikembangkan, dan 4) merancang evaluasi.

Uji coba produk dilakukan untuk mengetahui validitas produk. Uji coba produk dilakukan dengan uji ahli, uji guru, dan uji siswa. Uji coba dilakukan untuk mengetahui masukan seperti penilaian, komentar, kritik, dan saran sebagai bahan revisi. Produk bahan ajar ini akan diujikan terhadap ahli, pengajar, dan mahasiswa BIPA. Uji coba menggunakan angket sebagai bahan revisi dan pengumpulan data. Data dari pengajar digunakan sebagai dasar untuk perbaikan produk. Bahan ajar yang sudah direvisi akan diujicobakan pada mahasiswa BIPA. Subjek uji coba terdiri atas ahli yang memiliki kepakaran di bidang BIPA dan memiliki masa kerja minimal 5 tahun dengan kualifikasi minimal magister, pengajar BIPA yang memiliki masa kerja minimal 5 tahun dengan kualifikasi minimal sarjana, dan 6 mahasiswa BIPA UIN Raden Mas Said Surakarta.

Pendekatan penelitian yang digunakan peneliti adalah pendekatan pengembangan. Peneliti mendeskripsikan pembelajaran membaca BIPA dan mengembangkannya dalam bentuk bahan ajar. Data dalam pengembangan adalah kurikulum Pusat Pengembangan Strategi dan Diplomasi Kebahasaan (PPSDK) yang diintegrasikan dengan wawasan budaya dan keislaman, daftar rujukan mengenai teori membaca, pengajaran, bahan pembelajaran, dan RPP keterampilan membaca BIPA.

Data hasil uji coba dalam penelitian ini adalah data verbal dan skor nilai yang telah diujikan kepada mahasiswa asing di UIN Raden Mas Said Surakarta pada semester genap tahun 2019. Data verbal berupa catatan, saran, komentar, kritik, usulan dan koreksi langsung dari pakar dan pengajar BIPA. Data uji coba yang diperoleh dari skor nilai dimanfaatkan sebagai bahan pertimbangan untuk menilai dan merevisi tingkat validitas produk. Dalam penelitian ini peneliti bertindak sebagai instrumen kunci. Instrumen data uji coba produk berupa angket. Angket digunakan untuk menghimpun data dari ahli, pengajar BIPA, dan mahasiswa BIPA.

Teknik analisis data pengembangan ini dilakukan melalui (1) transkripsi data verbal dari hasil wawancara dengan ahli dan pengajar BIPA, (2) pembuatan peta penyusunan bahan ajar, (3) pembuatan RPP, dan (4) penulisan dan penyusunan bahan ajar. Teknik pengumpulan data dan uji coba dilakukan dengan cara (1) mengumpulkan data verbal yang diperoleh dari hasil wawancara dan data diri angket, (2) mencatat data-data yang masuk secara lisan dan tulis, (3) menghimpun, menyeleksi dan mengklarifikasi data yang sudah masuk, dan (4) menganalisis dan merumuskan hasil analisis untuk digunakan dalam penyelesaian akhir 
pengembangan bahan ajar keterampilan membaca untuk mahasiswa BIPA UIN Raden Mas Said Surakarta.

\section{PEMBAHASAN}

\section{Pengembangan Model Graves untuk Keterampilan Membaca Mahasiswa BIPA di UIN Raden Mas Said Surakarta}

Pengembangan bahan ajar ini mempunyai tujuan untuk 1) menganalisis kebutuhan bahan ajar, 2) mengetahui tujuan umum dan tujuan khusus bahan ajar, 3) memilah dan menyeleksi materi ajar dan aktivitas yang dikembangkan, dan 4) mengorganisasikan isi dan aktivitas.

\section{1) Analisis Kebutuhan Bahan Ajar}

Penyusunan bahan ajar BIPA UIN Raden Mas Said Surakarta, khususnya membaca didasarkan pada latar belakang mahasiswa asing yang sedang belajar di lembaga tersebut. Hal tersebut dilakukan agar bahan ajar yang telah disusun mampu membantu mahasiswa asing dalam belajar bahasa. Setiap materi yang terdapat dalam bahan ajar selalu dikaitkan dengan perkembangan dan pengetahuan mereka. Berikut ini beberapa aspek yang menjadi pertimbangan dalam penyusunan bahan ajar ini. Data diperoleh peneliti dari hasil pengisian form data diri mahasiswa BIPA UIN Raden Mas Said Surakarta.

a) Usia

Usia menjadi dasar analisis kebutuhan dalam bahan ajar ini. Dengan mengetahui perkembangan usia mahasiswa asing, penyusun bahan ajar khusunya membaca akan lebih mudah dalam memilih materi bacaan yang tepat. Secara umum, mahasiswa yang belajar di BIPA UIN Raden Mas Said Surakarta berjumlah enam orang dan rata-rata berusia 20 tahun. Jika dilihat dari tingkat usianya, perkembangan emosional dan kemampuan berpikir kritis dari setiap mahasiswa akan didapat. Berdasarkan hal tersebut, materi dalam bahan ajar ini mengintegrasikan beberapa ilmu pengetahuan dan keterampilan yang dibutuhkan oleh mahasiswa asing sesuai dengan tingkatannya.

b) Asal Negara

Secara kesuluruhan mahasiswa asing yang belajar di BIPA UIN Raden Mas Said Surakarta ini berasal dari negara Thailand. Perbedaan latar belakang bahasa dan budaya menjadi tantangan penyusun bahan ajar membaca. Penyusun bahan ajar harus mampu menyesuaikan antara budaya Thailand dan Indonesia. Selain itu, persamaan rumpun bahasa yakni Melayu-Austronesia menjadikan penggunaan bahasa dalam bahan ajar semakin mudah. c) Pendidikan Terakhir

Berdasarkan data enam mahasiswa asing yang sedang belajar di lembaga BIPA UIN Raden Mas Said Surakarta, pendidikan terakhir mereka yakni lulusan SMA/sederajat. Latar belakang pendidikan tersebut dapat menunjukkan tingkat perkembangan dan pengetahuan mereka sehingga penyusunan bahan ajar ini disesuaikan dengan perkembangan pengetahuan mereka. Dengan demikian, penyusunan bahan ajar ini menjadi tepat sasaran dan tujuan.

d) Calon Profesi

Dari enam data mahasiswa asing, banyak di antara mereka yang bercita-cita ingin menjadi pendidik atau guru. Sebagian besar di antara mereka sedang menempuh studi tentang bahasa, baik Indonesia maupun Inggris di UIN Raden Mas Said Surakarta. Penggunaan bahasa Indonesia dalam setiap pembelajaran di UIN Raden Mas Said Surakarta tentunya bertujuan untuk mempermudah komunikasi. Hal tersebut menuntut mahasiswa asing yang akan belajar mampu menguasai Bahasa Indonesia terlebih dahulu sehingga penyusunan bahan ajar ini disesuaikan dengan berbagai kegiatan yang terdapat dalam lingkup sehari-hari. Mulai dari perkenalan, kegiatan membaca, dan seterusnya. 


\section{e) Bahasa yang Dikuasai}

Secara umum bahasa yang dikuasai oleh mahasiswa asing yaitu bahasa Thailand dan Melayu. Hal tersebut dipengaruhi oleh pemerolehan bahasa pertama oleh mahasiswa asing. Jadi, belajar bahasa Indonesia merupakan proses pemerolehan bahasa kedua atau ketiga. Dalam pemerolehan bahasa kedua ini tentunya tidak mudah karena banyak unsur bahasa pertama yang mengikuti bahasa kedua. Berdasarkan fakta tersebut, penyusunan bahan ajar ini disesuaikan dengan kemampuan awal mereka. Bahasa yang digunakan juga mampu dipahami mahasiswa asing.

f) Pemahaman terhadap Bahan Ajar BIPA Saat Ini

Dari 6 mahasiswa yang mengisi kuisioner 90\% menyatakan bahwa bacaan yang terdapat dalam buku ajar BIPA saat ini sudah jelas. Sedangkan 10\% lainnya menyatakan belum jelas. Hal tersebut dapat dibuktikan dengan beberapa pernyataan mahasiswa melalui kuesioner. Namun demikian, secara keseluruhan bahan bacaan yang terdapat dalam buku ajar BIPA tidak terlalu sulit untuk dipahami. Selain itu, adanya penjelasan dari pengajar BIPA semakin memudahkan mereka untuk memahami maksud dari bacaan tersebut.

g) Kesulitan yang dialami mahasiswa asing ketika membaca bacaan dalam bahan ajar BIPA

Dari 6 mahasiswa yang mengisi kuesioner, 90\% menyatakan kesulitannya terletak pada pemahaman kosakata bahasa Indonesia. Sementara itu, 10\% lainnya menyatakan bahwa kesulitannya terletak pada kelancaran berbahasa Indonesia dan tugas yang diberikan oleh pengajar BIPA.

h) Kritik dan saran terhadap bahan ajar BIPA selanjutnya

Berdasarkan kuesioner yang telah diisi oleh mahasiswa asing, diperoleh simpulan bahwa kritik dan saran bagi buku ajar BIPA selanjutnya untuk diberikan banyak latihan atau kuis sehingga menambah pemahaman mereka terhadap bacaan. Selain itu, terdapat beberapa usulan tentang kemudahan dalam memahami kosakata baru dalam bahasa Indonesia, serta setiap mahasiswa diberi satu buku ajar BIPA.

\section{2) Tujuan Umum dan Tujuan Khusus Bahan Ajar}

Penyusunan bahan ajar ini disesuaikan dengan kurikulum BIPA PPSDK, yang diintegrasikan dengan pengetahuan tentang bahasa, budaya, dan wawasan keislaman. Dengan demikian, selain memberikan pengetahuan akan bahasa juga terselip nilai-nilai budaya dan keislaman yang berlaku dalam kehidupan sehari-hari. Berikut tujuan umum dan khusus dalam penyusunan bahan ajar BIPA ini.

a) Tujuan Umum

Tujuan umum dari penyusunan bahan ajar ini adalah agar mahasiswa asing mampu mengaplikasikan keterampilan membaca secara baik dan benar. Dalam bahan ajar ini mencakup beberapa bacaan yang sesuai dengan kurikulum BIPA PPSDK yang secara umum materinya berkaitan dengan kehidupan sehari-hari sehingga semakin membantu mahasiswa asing belajar bahasa Indonesia. Selain itu, bahan ajar ini disusun agar para pemelajar BIPA mampu mengaplikasikan materinya dalam berkomunikasi langsung dengan orang Indonesia.

\section{b) Tujuan Khusus}

Adapun tujuan khusus dalam penyusunan bahan ajar ini adalah agar materinyamampu memperkenalkan nilai budaya dan wawasan keislaman kepada mahasiswa pemelajar BIPA. Setiap bacaan dalam bahan ajar selalu terintegrasi dengan nilai budaya dan keislaman yang berlaku di lingkungan sekitar. Hal tersebut didasarkan pada kewajiban mahasiswa asing yang akan belajar di UIN Raden Mas Said Surakarta harus mampu menerapkan prinsip dan nilai keislaman yang berlaku. Oleh karena itu, mereka tidak hanya mahir dalam menggunakan bahasa yang dipelajari, tetapi juga dalam hal budaya dan wawasan keislaman. 


\section{3) Hasil Pemilahan dan Penyeleksian Materi Ajar}

a) Pemilahan dan Penyeleksian Bahan Ajar

Bahan ajar BIPA dengan pengembangan model Graves ini, disusun dengan mempertimbangkan kebutuhan mahasiswa BIPA. Pemetaan kebutuhan bahan ajar mahasiswa BIPA UIN Raden Mas Said Surakarta, yaitu (1) petunjuk materi yang jelas di dalam buku, (2) adanya foto dan gambar dalam buku semakin menambah ketertarikan dalam belajar, (3) adanya gambar dan foto pada bahan ajar yang sesuai dengan topiknya, (4) contoh-contoh dalam bahan ajar semakin memudahkan dalam memahami materi, (5) bahasa, kosakata dan kalimat dalam bahan ajar mudah dipahami, (6) paragraf pada bahan ajar tidak terlalu panjang (pendek), (7) diberi kemudahan dalam memahami kosakata baru, (8) diberikan ruang kosong untuk mencatat poin-poin penting yang ada di tiap unit modul, (9) dda kegiatan pembelajaran membaca yang dilaksanakan di luar kelas, (10) bahan ajar memberikan banyak latihan dan kuis, (11) setiap mahasiswa diberi satu buku ajar, dan (12) adanya tema-tema yang ingin dipelajari mahasiswa BIPA.

b) Hasil Uji Coba Bahan Ajar

\section{(1)Pengembangan Bahan Ajar Keterampilan Membaca Model Graves Mahasiswa BIPA}

Uji coba produk dilakukan kepada satu pakar/ahli yaitu Dr. Kundharu Saddhono, M.Hum. yang disebut ahli 1 dan uji guru kepada pengajar BIPA UIN Raden Mas Said Surakarta yaitu Elita Ulfiana, S.S., M.A. Hasil uji coba bahan ajar keterampilan membaca bahasa Indonesia mengenai kesesuaian kompetensi dasar menunjukkan bahwa terdapat penilaian baik oleh ahli 1 dan sangat baik oleh guru sehingga tidak perlu adanya revisi. Hasil uji coba mengenai kesesuaian kompetensi dasar dengan indikator menunjukan bahwa terdapat penilaian yang baik oleh ahli 1 dan sangat baik oleh guru sehingga tidak perlu adanya revisi. Berikut ini disajikan analisis data pengembangan kompetensi dasar yang diperoleh dari ahli dan guru pengajar BIPA UIN Raden Mas Said Surakarta.

Tabel 1

Analisis Data Pengembangan Kompetensi Dasar

\begin{tabular}{|c|c|c|c|c|c|c|c|c|c|}
\hline \multirow{2}{*}{ No } & \multirow{2}{*}{ Kriteria } & \multicolumn{4}{|c|}{ Uji Ahli } & \multicolumn{4}{|c|}{ Uji Guru } \\
\hline & & 4 & 3 & 2 & 1 & 4 & 3 & 2 & 1 \\
\hline 1. & $\begin{array}{l}\text { Kesesuaian kompetensi dasar dengan } \\
\text { kurikulum. }\end{array}$ & & $\sqrt{ }$ & & & $\sqrt{ }$ & & & \\
\hline 2. & Kompetensi dasar sesuai dengan indikator & & $\sqrt{ }$ & & & $\sqrt{ }$ & & & \\
\hline
\end{tabular}

Keterangan:

4= Penilaian sangat baik, $3=$ penilaian baik, $2=$ penilaian cukup, $1=$ penilaian kurang

Dari tabel di atas, butir kesesuaian kompetensi dasar dengan kurikulum mendapat penilaian sangat baik dan baik. Butir kedua yaitu kesesuaian kompetensi dasar dengan idikator mendapat penilaian sangat baik dan baik.

\section{(2)Hasil Pengembangan Isi Materi Ajar}

Pengembangan bahan ajar telah diujicobakan dalam bentuk materi pembelajaran yang disesuaikan dengan standar kompetensi kurikulum Pusat Pengembangan Strategi dan Diplomasi Kebahasaan (PPSDK). Materi yang disajikan dalam bahan ajar BIPA adalah sebagai berikut.

Buku ajar A1 meliputi, (1) menyapa, (2) identitasku, (3) keluarga, (4) perayaan ulang tahun, (5) lingkungan sekitar, (6) penyayang binatang, (7) denah lokasi, (8) aku dan hobiku, dan (9) rumah Rofiah. Buku ajar A2 meliputi, (1) media sosial, (2) kebersihan, (3) membeli buku baru, (4) berlibur, (5) makanan Indonesia, (6) cita-citaku, (7) film, (8) pekerjaan, (9) tempat umum, (10) berolahraga, (11) transportasi online, dan (12) lomba 17 Agustus. 
Materi yang disajikan dalam bahan ahjar BIPA ini disajikan dengan gambar, ilustrasi, foto, dan contoh yang sesuai dengan pembelajaran. Bahan ajar disajikan dengan menarik agar mahasiswa lebih bersemangat dalam mengikuti pembelajaran khususnya pada keterampilan membaca. Analisis data hasil uji coba ahli dan guru ditunjukan pada tabel berikut.

Tabel 2

Analisis Data Hasil Uji Coba Ahli Dan Guru

\begin{tabular}{|c|c|c|c|c|c|c|c|c|c|}
\hline \multirow{2}{*}{ No } & \multirow{2}{*}{ Kriteria } & \multicolumn{4}{|c|}{ Uji Ahli } & \multicolumn{4}{|c|}{ Uji Guru } \\
\hline & & 4 & 3 & 2 & 1 & 4 & 3 & 2 & 1 \\
\hline 1. & $\begin{array}{l}\text { Bahan ajar sebagai media untuk } \\
\text { mempermudah siswa dalam belajar. } \\
\text { Khususnya membantu mereka dalam } \\
\text { mengembangkan } \\
\text { keterampilan dalam berbagai bentuk } \\
\text { kegiatan. }\end{array}$ & & $\sqrt{ }$ & & & & $\sqrt{ }$ & & \\
\hline 2. & $\begin{array}{l}\text { Kesesuaian materi membaca dengan } \\
\text { kompetensi dasar dalam kurikulum. }\end{array}$ & & $\sqrt{ }$ & & & $\sqrt{ }$ & & & \\
\hline 3. & $\begin{array}{l}\text { Kesesuaian antara materi membaca } \\
\text { dengan tingkat pengetahuan siswa. }\end{array}$ & & $\sqrt{ }$ & & & $\sqrt{ }$ & & & \\
\hline 4. & $\begin{array}{l}\text { Kemutahiran materi membaca } \\
\text { disesuaikan dengan kebutuhan siswa. }\end{array}$ & & $\sqrt{ }$ & & & & $\sqrt{ }$ & & \\
\hline 5. & $\begin{array}{l}\text { Kejelasan petujuk dalam setiap } \\
\text { kegiatan pembelajaran, baik bagi guru } \\
\text { dan siswa. }\end{array}$ & & $\sqrt{ }$ & & & $\sqrt{ }$ & & & \\
\hline 6. & $\begin{array}{l}\text { Kemanfaatan isi bahan ajar membaca } \\
\text { bagi siswa. }\end{array}$ & & $\sqrt{ }$ & & & & $\sqrt{ }$ & & \\
\hline 7. & $\begin{array}{l}\text { Kemampuan bahan ajar menambah } \\
\text { wawasan siswa tentang kearifan } \\
\text { budaya lokal. }\end{array}$ & & $\sqrt{ }$ & & & & & $\sqrt{ }$ & \\
\hline 8. & $\begin{array}{l}\text { Ketersediaan kegiatan bagi siswa untuk } \\
\text { melaksanakan kegiatan di luar kelas. }\end{array}$ & $\sqrt{ }$ & & & & & $\sqrt{ }$ & & \\
\hline 9. & $\begin{array}{l}\text { Kelengkapan modul dengan adanya } \\
\text { latihan dan evaluasi. }\end{array}$ & & $\sqrt{ }$ & & & & $\sqrt{ }$ & & \\
\hline
\end{tabular}

Dari tabel di atas, butir 1 mendapat nilai baik oleh pakar/ahli dan guru. Butir kedua mendapat penilaian baik oleh ahli dan sangat baik oleh guru. Butir 3 mendapat nilai baik oleh ahli dan sangat baik oleh guru. Butir 4 mendapat nilai baik oleh ahli dan guru. Butir 5 dinilai baik oleh ahli dan sangat baik oleh guru. Butir 6 dinilai baik oleh ahli dan guru. Butir 7 dinilai baik oleh ahli dan cukup oleh guru. Butir 8 dinilai sangat baik oleh ahli, baik oleh guru. Butir 9 dinilai baik oleh ahli dan guru.

Tabel 3

Hasil Uji Coba Siswa Ditunjukan

\begin{tabular}{llcc}
\hline \multirow{2}{*}{ No } & \multicolumn{1}{c}{ Kriteria } & Ya & Tenilaian \\
\cline { 2 - 4 } & \multicolumn{1}{c}{$\begin{array}{l}\text { Apakah materi membaca bahasa } \\
\text { Indonesia menambah pengetahuan dan } \\
\text { keterampilanmu? }\end{array}$} & 6 mahasiswa & - \\
\hline 1. & $\begin{array}{l}\text { Apakah petunjuk dalam materi bahan } \\
\text { ajar sudah jelas? }\end{array}$ & 5 mahasiswa & 1 siswa \\
\hline 3. & $\begin{array}{l}\text { Apakah dengan modul ini kamu dapat } \\
\text { dengan mudah mahami } \\
\text { pembelajaran? }\end{array}$ & 6 mahasiswa & - \\
\hline 4. & $\begin{array}{l}\text { Apakah isi modul dapat menambah } \\
\text { wawasanmu? }\end{array}$ & 6 mahasiswa & -
\end{tabular}




\begin{tabular}{llll}
\hline 5. & $\begin{array}{l}\text { Apakah kegiatan yang disajikan dalam } \\
\text { modul membuat kamu tertarik untuk } \\
\text { belajar? }\end{array}$ & 6 mahasiswa & - \\
\hline 7. & $\begin{array}{l}\text { Apakah modul dilengkapi dengan } \\
\text { latihan dan evaluasi? }\end{array}$ & 6 mahasiswa & - \\
\hline
\end{tabular}

Analisis data pengembangan isi materi bahan ajar menunjukkan bahwa dalam bahan ajar keterampilan membaca bahasa Indonesia ada yang harus direvisi. Revisi bahan ajar dilakukan agar bahan ajar mengalami perbaikan. Hasil data menunjukkan bahwa isi bahan ajar belum menambah wawasan siswa tentang kearifan budaya lokal karenaarena pada bahan ajar yang belum direvisi, wawasan budaya lokal dan keislaman hanya terdapat di 1 unit. Aspek kemanfaatan isi bahan ajar bagi siswa juga perlu direvisi pada kejelasan petunjuk dalam materi bahan ajar. Produk yang telah direvisi, setiap unitnya sudah dilengkapi dengan subbab yang khusus membahas wawasan budaya lokal dan keislaman.

\section{(3)Hasil Pengembangan Penyajian Bahan Ajar}

Berdasarkan data yang dihimpun dari hasil uji coba pakar/ahli dan guru mengenai penyajian bahan ajar yang disajikan sesuai dengan keteranpilan membaca bahasa Indonesia, berikut data dari hasil uji pakar/ahli dan guru ditujukan pada tabel.

Tabel 4

Hasil Penyajian Bahan Ajar

\begin{tabular}{|c|c|c|c|c|c|c|c|c|c|}
\hline \multirow{2}{*}{ No } & \multirow{2}{*}{ Kriteria } & \multicolumn{4}{|c|}{ Uji Ahli } & \multicolumn{4}{|c|}{ Uji Guru } \\
\hline & & 4 & 3 & 2 & 1 & 4 & 3 & 2 & 1 \\
\hline 1. & $\begin{array}{l}\text { Ketersediaan pembangkit motivasi yang berupa } \\
\text { gambar, ilustrasi, foto, dan warna-warna pada } \\
\text { setiap unit. }\end{array}$ & & & $\sqrt{ }$ & & & $\sqrt{ }$ & & \\
\hline 2. & $\begin{array}{l}\text { Ketersediaan bagian pendahuluan yang memuat } \\
\text { tujuan pembelajaran untuk memahami bahan } \\
\text { ajar utama yang disajikan. }\end{array}$ & & $\sqrt{ }$ & & & $\sqrt{ }$ & & & \\
\hline 3. & $\begin{array}{l}\text { Ketersediaan konteks yang dekat dengan } \\
\text { lingkungan siswa pada setiap bagian bahan ajar } \\
\text { untuk memudahkan pemahaman siswa. }\end{array}$ & & $\sqrt{ }$ & & & $\sqrt{ }$ & & & \\
\hline 4. & $\begin{array}{l}\text { Ketersediaan contoh-contoh konkret dan aktual } \\
\text { pada setiap bagian bahan ajar sehingga } \\
\text { mempercepat pencapaian indikator hasil belajar } \\
\text { siswa. }\end{array}$ & & $\sqrt{ }$ & & & $\sqrt{ }$ & & & \\
\hline 5. & $\begin{array}{l}\text { Konsistensi pola urutan dan komponen sajian } \\
\text { pada setiap unit. }\end{array}$ & & & $\sqrt{ }$ & & & $\sqrt{ }$ & & \\
\hline 6. & $\begin{array}{l}\text { Kesesuaian antara topik dan teks bacaan di tiap } \\
\text { unit. }\end{array}$ & & $\sqrt{ }$ & & & $\sqrt{ }$ & & & \\
\hline 7. & $\begin{array}{l}\text { Ketersediaan lembar kosong bagi siswa untuk } \\
\text { menuliskan hal-hal penting yang ingin dicatat. }\end{array}$ & $\sqrt{ }$ & & & & $\sqrt{ }$ & & & \\
\hline
\end{tabular}

Keterangan:

4= Penilaian sangat baik, $3=$ penilaian baik, $2=$ penilaian cukup, $1=$ penilaian kurang

Dari tabel di atas, butir 2, 3, 4, 6, dan 7 mendapat nilai sangat baik dan baik oleh pakar/ahli dan guru sehingga tidak perlu ada revisi. Sedangkan butir 1 dan 5 mendapat nilai cukup oleh ahli sehingga memerlukan revisi.

Data yang dihimpun dari hasil uji coba terhadap enam mahasiswa BIPA UIN Raden Mas Said Surakarta mengenai; 1) gambar dan foto dalam bahan ajar dapat menambah ketertarikan mahasiwa dalam belajar, 2) gambar dan foto yang ada sesuai dengan topiknya, 3) contoh-contoh yang ada sudah membantu siswa memahami materi,dan 4) bahan ajar ini menyediakan lembar kosong untk menuliskan hal-hal penting menunjukkan bahwa semua 
mahasiswa menjawab "Ya". Data temuan dari hasil uji coba siswa ditunjukkan pada tabel berikut.

Tabel 5

Hasil Uji Coba Siswa

\begin{tabular}{llcl}
\hline \multirow{2}{*}{ No } & \multicolumn{1}{c}{ Kriteria } & Ya & Penilaian \\
\cline { 3 - 4 } 1. & $\begin{array}{l}\text { Apakah dengan gambar dan foto di } \\
\text { modul ini dapat menambah } \\
\text { ketertarikanmu dalam belajar? }\end{array}$ & 6 mahasiswa & - \\
\hline 2. & $\begin{array}{l}\text { Apakah gambar dan foto yang ada } \\
\text { sesuai dengan topiknya? }\end{array}$ & 6 mahasiswa & - \\
\hline & $\begin{array}{l}\text { Apakah contoh-contoh yang ada sudah } \\
\text { membantumu memahami materi? }\end{array}$ & 6 mahasiswa & - \\
3. & $\begin{array}{l}\text { Apakah di modul ini meyediakan } \\
\text { lembar kosong untuk menuliskan hal- } \\
\text { hal penting yang ingin kamu catat? }\end{array}$ & 6 mahasiswa & - \\
\hline
\end{tabular}

Hasil uji pakar/ahli dan guru dan mahasiswa menunjukkan bahwa perlu adaya revisi pada ketersediaan pembangkit motivasi berupa gambar, ilustrasi, foto, dan warna-warna pada setiap unit serta konsistensi pola urutan dan komponen sajian pada setiap unit. Untuk butir 5, ahli memberi nilai cukup karena di modul ajar yang belum direvisi, ada 1 unit yang kelebihan jumlah halaman. Jumlah halaman tiap unit biasanya berkisar antara $4-6$ halaman, sedangkan pada unit 3 A2 (dengan tema Membeli Buku), ada 7 halaman. Untuk itu, pada modul ajar yang sudah direvisi, unit 3 pada modul A2 diubah menjadi enam halaman saja.

\section{(4)Hasil Pengembangan Kelayakan Bahasa Bahan Ajar}

Berdasarkan data yang dihimpun dari hasil uji coba pakar/ahli dan guru mengenai kelayakan bahasa bahan ajar, berikut data dari hasil uji pakar/ahli dan guru yang ditunjukkan pada tabel.

Tabel 6

Hasil Uji Pakar/Ahli Dan Guru

\begin{tabular}{|c|c|c|c|c|c|c|c|c|c|}
\hline \multirow{2}{*}{ No } & \multirow{2}{*}{ Kriteria } & \multicolumn{4}{|c|}{ Uji Ahli } & \multicolumn{4}{|c|}{ Uji Guru } \\
\hline & & 4 & 3 & 2 & 1 & 4 & 3 & 2 & 1 \\
\hline 1. & $\begin{array}{l}\text { Bahasa yang digunakan dalam bahan ajar } \\
\text { ini sesuai dengan tingkat perkembangan } \\
\text { intelektual mahasiswa BIPA level dasar. }\end{array}$ & & & $\sqrt{ }$ & & & $\sqrt{ }$ & & \\
\hline 2. & $\begin{array}{l}\text { Bahasa dalam bahan ajar ini sessuai } \\
\text { dengan tingkat perkembangan emosional } \\
\text { mahasiswa BIPA level dasar. }\end{array}$ & & $\sqrt{ }$ & & & & $\sqrt{ }$ & & \\
\hline 3. & $\begin{array}{l}\text { Pesan yang disampaikan dalam bahan ajar } \\
\text { ini mengunakan bahasa yang menarik, } \\
\text { jelas, dan tidak menimbulkan makna } \\
\text { ganda. }\end{array}$ & & & $\sqrt{ }$ & & & & $\sqrt{ }$ & \\
\hline 4. & $\begin{array}{l}\text { Ejaan, tanda bacam dan aspek-aspek } \\
\text { mekanik digunakan secara tepat dalam } \\
\text { bahan ajar ini. }\end{array}$ & & & $\sqrt{ }$ & & & $\sqrt{ }$ & & \\
\hline 5. & $\begin{array}{l}\text { Pilihan kata, bentukan kata, dan struktur } \\
\text { kalimat yang digunakan dalam bahan ajar } \\
\text { ini sesuai dengan kaidah Bahasa Indonesia } \\
\text { yang benar dan baik. }\end{array}$ & & $\sqrt{ }$ & & & & $\sqrt{ }$ & & \\
\hline 6. & $\begin{array}{l}\text { Paragraf-paragraf dalam bahan ajar ini } \\
\text { disusun dengan baik, mudah dipahami, } \\
\text { dan sesuai dengan perkembangan } \\
\text { mahasiswa BIPA level dasar. }\end{array}$ & & $\sqrt{ }$ & & & & $\sqrt{ }$ & & \\
\hline
\end{tabular}




\begin{tabular}{ll}
\hline 7. Secara keseluruhan, bahasa yang & $\sqrt{ }$ \\
digunakan dalam penyajian bahan ajar ii \\
menarik dan komunikatif.
\end{tabular}

Dari tabel di atas, butir 2, 5, 6, dan 7 mendapat nilai Baik dan Sangat Baik oleh ahli dan guru, sehingga tidak memerlukan revisi. Butir 1, 3, dan 4 mendapat nilai cukup oleh ahli. Butir 3 juga mendapat nilai Cukup oleh guru, sehingga memerlukan revisi.

Berdasarkan data yang dihimpun dari hasil uji coba terhadap 6 mahasiswa BIPA UIN Raden Mas Said Surakarta mengenai; 1) kemudahan bahasa dalam modul nntuk dipahami, 2) kata-kata (kosakata) dalam modul memudahkan mahasiswa untuk memahami, 3) kalimatkalimat dalam modul ini pendek dan mudah dipahami, 4) paragraf dalam modul ini cukup dan tidak terlalu panjang, 5) pesan-pesan dalam modul ini dapat dipahami dengan jelas, 6) bahasa dalam modul ini sudah membuat siswa tertarik untuk belajar, menunjukkan bahwa semua siswa sepakat menjawab "ya". Data temuan dari hasil uji coba siswa ditunjukkan pada tabel berikut.

Tabel 7

Data Temuan Hasil Uji Coba Siswa

\begin{tabular}{llll}
\hline \multirow{2}{*}{ No } & \multicolumn{1}{c}{ Kriteria } & \multicolumn{2}{c}{ Penilaian } \\
\cline { 2 - 4 } 1. & $\begin{array}{l}\text { Apakah bahasa dalam modul ini mudah } \\
\text { dipahami? }\end{array}$ & 6 siswa & Tidak \\
\hline 2. & $\begin{array}{l}\text { Apakah kata-kata (kosakata) dalam modul ini } \\
\text { mudah kamu pahami? }\end{array}$ & 6 siswa & - \\
\hline 3. & $\begin{array}{l}\text { Apakah kalimat-kalimat dalam modul ini } \\
\text { pendek dan mudah kamu pahami? }\end{array}$ & 6 siswa & - \\
\hline 4. & $\begin{array}{l}\text { Apakah paragraf dalam modul ini cukup dan } \\
\text { tidak terlalu panjang? }\end{array}$ & 6 siswa & - \\
\hline 5. & $\begin{array}{l}\text { Apakah pesan-pesan dalam modul ini dapat } \\
\text { kamu pahami dengan jelas? }\end{array}$ & 6 siswa & - \\
\hline Ap. & $\begin{array}{l}\text { Apakah bahasa dalam modul ini sudah } \\
\text { membuatmu tertarik untuk belajar? }\end{array}$ & 6 siswa & - \\
\hline
\end{tabular}

Hasil uji siswa menujukkan bahwa perlu adanya revisi pada beberapa bagian: 1) Bahasa yang digunakan dalam bahan ajar ini yang kurang sesuai dengan tingkat perkembangan intelektual mahasiswa BIPA level dasar, 2) Pesan yang disampaikan dalam bahan ajar ini mengunakan bahasa yang kurang menarik, kurang jelas, atau menimbulkan makna ganda, dan 3) Ejaan, tanda baca dan aspek-aspek mekanik belum digunakan secara tepat dalam bahan ajar ini.

\section{4) Organisasi Isi dan Aktivitas Bahan Ajar}

Bahan ajar BIPA UIN Raden Mas Said Surakarta disusun dengan mengintegrasikan kurikulum Pusat Pengembangan Strategi dan Diplomasi Kebahasaan (PPSDK) dengan wawasan budaya dan keislaman yang terdapat di lingkungan sekitar. Cakupan materi yang terdapat dalam bahan ajar ini meliputi dua level yakni A1 dan A2. Setiap materi terdapat indikator yang telah disusun berdasarkan level atau tingkatannya. Dari bahan ajar khususnya membaca, mahasiswa asing akan diperkenalkan mengenai ragam budaya Indonesia berserta keunikan yang terdapat di dalamnya. Tujuan dari adanya penambahan unsur budaya dan wawasan keislaman adalah mahasiswa asing mampu mengenal ragam budaya yang terdapat di Indonesia, lebih khususnya lagi budaya di Kota Solo (mengedepankan unsur lokalitas). Selain itu, agar mahasiswa mahir dalam berbahasa Indonesia baik secara lisan dan tulis sehingga 
dapat membantu mereka memahami setiap tradisi masyarakat Indonesia dalam kehidupan sehari-hari.

Setiap materi dalam bahan ajar membaca selalu terselip pengetahuan tentang budaya dan keislaman. Keduanya terintegrasi secara padu dan ringkas dalam bentuk sebuah bacaan. Kedua unsur tersebut saling berkaitan dan saling melengkapi dengan yang lainnya. Hal inilah yang membedakan bahan ajar BIPA UIN dengan yang lainnya. Terdapat penciri kususnya, yakni tidak hanya seputar bahasa yang dibahas melainkan juga budaya dan wawasan keislaman. Hal ini didasarkan bahwa lembaga BIPA berada di bawah PTKIN sehingga mahasiswa asing yang belajar, diwajibkan menguasai bahasa, budaya, dan nilai-nilai keislaman yang berlaku di dalamnya.

Bahan ajar ini disusun juga untuk memudahkan tujuan pembelajaran khususnya kelas membaca. Digunakan sebagai media pendukung pembelajaran, baik bagi guru dan mahasiswa asing. Bahan ajar ini mengambil tema "Belajar Bahasa Indonesia Melalui Kearifan Budaya". Tema tersebut disesuaikan dengan isi bahan ajar. Secara umum mencakup materi yang berhubungan dengan kebiasaan masyarakat Indonesia beserta budaya dan nilai-nilai keislaman yang diterapkan. Dari sudut budaya mahasiswa akan paham setiap kegiatan yang dilakukan masyarakat Indonesia. Dari sudut keagamaan, mereka akan mengetahui berbagai ajaran-ajaran yang diterapkan.

a) Organisasi Tema dalam Bahan Ajar

Bahan ajar ini mencakup dua level atau tingkatan, yakni A1 dan A2. Hal ini disesuaikan dengan kemampuan mahasiswa asing. Berdasarkan pengetahuan awal mereka mengenai bahasa Indonesia beserta unsur yang terdapat di dalamnya. Dapat diketahui tingkatan atau level yang sesuai dengan pembelajaran BIPA. Tingkatan dasar dalam pembeajaran BIPA mencakup beberapa pengetahuan dasar mengenai bahasa yakni seputar kosakata, kalimat.

Pada tingkat A1 meliputi beberapa tema, yakni menyapa, identitas, keluarga, perayaan uang tahun, lingkungan sekitar, penyayang binatang, denah lokasi, aku dan hobiku, rumah. Pada tingkat A2 mencakup tema mengenai media sosial, kebersihan, buku, berlibur, makanan Indonesia, cita-cita, film, pekerjaan, tempat umum, olahraga, transportasi online, peringatan hari kemerdekaan Indonesia.

Secara umum tema-tema tersebut dibedakan berdasarkan tingkat pemahaman awal mahasiswa asing sehingga tingkat kesulitannya pun masih sangat dasar. Tema tersebut diambil berdasarkan aktivitas yang biasa dilakukan oleh masyarakat Indonesia sehingga membantu mereka dalam memahami dan berkomunikasi dengan masyarakat Indonesia.

Bahan ajar membaca BIPA UIN Raden Mas Said Surakarta ini disusun dengan meliputi beberapa aspek, yakni sampul, kata pengantar, daftar isi, tema, dan lembar evaluasi dalam setiap bab. Struktur tersebut disesuaikan dengan bahan ajar dari PPSDK dengan penambahan di beberapa bagian sehingga tampilannya menjadi lebih menarik.

b) Deskripsi Isi Bahan Ajar

Dalam bagian ini memuat beberapa kegiatan pembelajaran.Bahan ajar membaca BIPA UIN Raden Mas Said Surakarta mencakup kegiatan yang menuntut mahasiswa asing belajar secara mandiri maupun kelompok. Dalam bahan ajar ini juga melatih mahasiswa untuk belajar di luar ruangan bersama masyarakat Indonesia. Kegiatan dalam bahan ajar membaca BIPA UIN Raden Mas Said Surakarta meliputi, (1) Judul Bab; (2) Indikator Pembelajaran; (3) Pengantar; (4) Ayo Membaca; (5) Kosakata; (6) Wawasan Budaya dan Keislaman; (7) Pemilihan Bentuk dan Ukuran Huruf.

\section{c) Tata Letak Bahan Ajar}

Bahan ajar membaca BIPA UIN Raden Mas Said Surakarta ini disusun dengan tata letak yang menarik dan sistematis. Hal tersebut dilakukan untuk menambah ketertarikan mahasiswa asing dalam belajar. Jarak antara satu kegiatan dengan kegiatan lainnnya juga 
memberiakn ruang bagi mahasiswa untuk mencatat hal penting. Bahan ajar ini juga didesain dengan warna cerah yaitu merah. Ilustrasi gambar yang terdapat di setiap materi juga dicantumkan agar mahasiswa tidak bosan dengan isi bahan ajar tersebut. Selain itu memperjelas dari materi yang dipelajari.

\section{d) Bahasa}

Bahasa yang digunakan dalam bahan ajar membaca BIPA disesuaikan dengan kemampuan awal mahasiswa asing. Pemilihan tersebut juga didasarkan pada perkembangan usia, pengetahuan, mental dan emosional mahasiswa asing. Berdasarkan aspek tersebut, bahasa dalam bahan ajar dibedakan menjadi bahasa formal dan nonformal.Selain itu juga harus komunikatif.Jadi bahasa yang sederhana menjadi fokus utama dalam penyusunan bahan ajar. Penyusun bahan ajar juga menghindari penggunaan istilah-istilah yang dianggap sulit untuk dipahami mahasiswa asing.

\section{5) Implikasi Pengembangan Bahan Ajar BIPA di Era Digital}

Perubahan dan perkembangan global memberikan tantangan tersendiri kepada pendidikan. Perubahan yang cepat dan masif dalam bidang ekonomi, teknologi, dan sosial membutuhkan transformasi pendidikan untuk menjawab kebutuhan pengembangan manusia yang mampu berkiprah pada era global dan membangun kreativitas dan potensi untuk berinovasi dalam berbagai bidang kehidupan (Suciati, 2018: 145).

Perkembangan teknologi di bidang pendidikan menuntut para ahli pendidikan untuk berkreativitas, berinovasi, dan berkreasi di berbagai aspek pendidikan. Misalnya, terhadap pembaruan penggunaan bahan ajar yang efektif dan efisien yang disesuaikan dengan kondisi kehidupan di era industri 4.0. Dalam hal penggunaaan bahan ajar pun harus disesuaikan dengan gaya hidup siswa saat ini yang lebih sering berinteraksi dengan gawai daripada bukubuku pelajaran. Dengan demikian, buku elektronik atau e-book perlu diberikan untuk menekan penggunaan gawai yang berlebihan.

E-book dapat digunakan sebagai salah satu sumber belajar. E-book merupakan buku dalam format elektronik berisikan informasi yang dapat berwujud teks atau gambar (Rosida, 2017: 8). E-book diminati karena ukurannya yang kecil, tidak mudah lapuk, dan mudah dibawa. Keunggulan e-book yang lain adalah dapat menampilkan ilustrasi multimedia, misalnya animasi. Siswa diharapkan lebih mandiri dalam pembelajaran menggunakan $e$-book interaktif sehingga kemampuan berpikir kritisnya dapat meningkat.

Pada buku produk hasil pengembangan bahan ajar BIPA keterampilan membaca tidak hanya diproduksi dalam bentuk hard file. Akan tetapi, dalam bentuk e-book dengan format PDF. Hal ini bertujuan untuk menunjang kemampuan mahasiswa asing dalam hal pembelajaran BIPA khusunya meningkatkan kemampuan pada keterampilan membaca. Selain itu, penggunaan bahan ajar dalam bentuk buku elektronik dapat memudahkan mahasiswa asing untuk mengakses dan mempelajarinya. Tidak hanya itu, buku elektronik dalam gawai mudah dibawa kemana saja dan dapat diakses kapan saja. Dengan demikian, dapat menunjang dan memudahkan mahasiswa asing untuk meningkatkan kemampuan berbahasa khususnya pada keterampilan membaca.

\section{PENUTUP}

Penyusunan bahan ajar membaca BIPA UIN Raden Mas Said Surakarta dikembangkan dengan model Graves melalui penyusunan bahan ajar BIPA UIN Raden Mas Said Surakarta memperhatikan analisis kebutuhan. Tujuan umum dari bahan ajar membaca BIPA, yakni 1) mahasiswa asing mampu memahami kosakata, dan 2) struktur kalimat dalam bahasa Indonesia secara baik dan benar. Secara khusus, mahasiswa mampu memahami dan menerapkan berbagai budaya dan nilai-nilai keislaman yang berlaku dalam kehidupan sehari- 
hari. Secara umum, bahan ajar membaca BIPA UIN Raden Mas Said Surakarta disusun dengan tampilan yang berbeda dan menarik. Materi yang terdapat di dalamnya mengintegrasikan antara bahasa, budaya, dan nilai-nilai keislaman. Unsur tersebut menjadi padu dengan adanya beberapa penambahan ilustrasi gambar beserta keterangan di gambar tersebut sehingga memudahkan mahasiswa asing dalam mempelajari bahan ajar membaca BIPA UIN Raden Mas Said Surakarta tersebut. Terdapat evaluasi dalam setiap bab dalam bentuk soal latihan dan tugas yang dapat digunakan guru untuk mengevaluasi kegiatan pembelajaran.

\section{DAFTAR PUSTAKA}

Andayani. (2015). The Correlation of Learning Motivation and Reasoning Ability to the Scientific Writing Skills of Students in Teaching Indonesian to Speakers of Other Languages ( TISOL ). International Journal of Science and Research (IJSR), 4(7), 1106-1110.

Andayani, \& Gilang, L. (2015). The Effectiveness of Integrative Learning Based Textbook toward the Local Culture Comprehension and Indonesian Language Skill of Foreign Students. International Journal of Humanities and Social Science, 5(10), 197-207.

Chen, S., Lawrence, J. F., Zhou, J., Min, L., \& Snow, C. E. (2018). Early Childhood Research Quarterly The efficacy of a school-based book-reading intervention on vocabulary development of young Uyghur children: A randomized controlled trial. Early Childhood Research Quarterly, 44, 206-219. https://doi.org/10.1016/j.ecresq.2017.12.008

Fariqoh, R. (2016). Pengembangan Bahan Ajar Membaca untuk Pembelajar Bahasa Indonesia Penutur Asing Tingkat Dasar. Riksa Bahasa, 2(2), 219-223.

Graves, K. (1996). Teachers as Course Developers. Cambridge: Cambridge University Press. https://doi.org/10.1017/CBO9780511551178

Haryati, G., Andayani, \& Anindyarini, A. (2019). The Complexity of Cultural Outcomes as Indonesian Language Teaching Material for Foreign Speakers ( BIPA ). International Journal of English, Literature and Social Sciences (IJELS), 4(6), 1979-1984. https://doi.org/10.22161/ijels.46.55

Hasanah, D. U., Kurniasih, D., \& Agustina, T. (2019). Analisis Kebutuhan Bahan Ajar Keterampilan Membaca pada Mahasiswa BIPA Tingkat Dasar di IAIN Surakarta. DIALEKTIKA: Jurnal Bahasa, Sastra, Dan Pendidikan Bahasa Dan Sastra Indonesia, 6(2), 114-125. https://doi.org/10.15408/dialektika.v6i2.10559

Hidayat, A. (2009). Penilaian Pembelajaran Membaca. Retrieved from http://pemerhatipendidikangowa.blogspot.com/2009/12/penilaian-pembelajaranmembaca_25.html?m=1

Jarvis, M. A., \& Baloyi, O. B. (2020). Scaffolding in reflective journaling: A means to develop higher order thinking skills in undergraduate learners. International Journal of Africa Nursing Sciences, 12(December 2019), 100195. https://doi.org/10.1016/j.ijans.2020.100195

Kurniasih, D. (2021). Analisis Bahan Ajar Bahasa Indonesia bagi Penutur Asing (BIPA) Sahabatku Indonesia Tingkat Dasar. Madah, 12(1), 25-45. https://doi.org/10.26499/jbipa.v1i2.1793

Kurniasih, D., \& Isnaniah, S. (2019). Penerapan Bahan Ajar Bahasa Indonesia bagi Penutur Asing (BIPA) "Sahabatku Indonesia" Tingkat Dasar di IAIN Surakarta. JBIPA, 1(2), 62-71. https://doi.org/10.26499/jbipa.v1i2.1793

Kusmiatun, A. (2016). Mengenal BIPA dan Pembelajarannya. Yogyakarta: K-Media.

Nurlina, L. (2017). Budaya Lokal Banyumas dalam Materi BIPA. In PIBSI XXXIX.

Nurlina, L., Andayani, Winarni, R., \& Slamet, S. Y. (2020). Development of Local Cultured Textbook for Improving the Speaking Ability of Foreign Workers in Indonesia. International Journal of Innovation, Creativity and Change, 11(3), 452-465.

O’Toole, K. J., \& Kannass, K. N. (2018). Emergent literacy in print and electronic contexts: The influence of book type, narration source, and attention. Journal of Experimental Child Psychology, 173, 100-115. https://doi.org/10.1016/j.jecp.2018.03.013

Prastowo, A. (2011). Panduan Kreatif Membuat Bahan Ajar Inovatif. Yogyakarta: Diva Press. 
Prodjo, W. A. (2020). Mendorong Bahasa Indonesia ke Tingkat Internasional. Retrieved from kompas.com

Rosida. (2017). Pengembangan Bahan Ajar E-Book Interaktif untuk Menumbuhkan Keterampilan Berpikir Kritis Siswa pada Materi Dampak Pencemaran bagi Kehidupan. Universitas Lampung.

Siroj, M. B. (2015). Pengembangan Model Integratif Bahan Ajar Bahasa Indonesia Ranah Sosial Budaya Berbasis ICT bagi Penutur Asing Tingkat Menengah. Jurnal Pendidikan Bahasa Dan Sastra Indonesia, 4(1), 74-84.

Suciati. (2018). Pengembangan Kreativitas Inovatif Melalui Pembelajaran Digital. Jurnal Pendidikan, 19(2), 145-154. https://doi.org/10.33830/jp.v19i2.181.2018

Sumaryani, S. (2020). Pengembangan Materi Ajar Ekonomi Indonesia dan Hukum Indonesia bagi Pembelajaran BIPA di Universitas Minzu Yunnan. In Konferensi Internasional Pengajaran Bahasa Indonesia bagi Penutur Asing (KIPBIPA) XI (pp. 344-355).

Tsuji, K., Takizawa, N., Sato, S., Ikeuchi, U., Ikeuchi, A., Yoshikane, F., \& Itsumura, H. (2014). Book Recommendation Based on Library Loan Records and Bibliographic Information. Procedia Social and Behavioral Sciences, 147, 478-486. https://doi.org/10.1016/j.sbspro.2014.07.142

Ulfiana, E. (2017). Di era MEA Bahasa Indonesia Menempati Posisi Strategis, IAIN Surakarta Menjadi Bagian Dari Empat Penyelenggara Lembaga BIPA Di PTKIN Seluruh Indonesia. Retrieved from http://www.iain-surakarta.ac.id/?p=7714

Van Peer, W., Zyngier, S., Klinger, K., \& Tosheff, L. (2010). Literary education and Digital Learning: methods and technologies for Humanities Studies Library of Congress Cataloging-inPublication Data. New York: Information Science Reference. https://doi.org/10.4018/978-160566-932-8 